\title{
Physical education and the comprehensive model in the inclusion of the university student. Year 2019
}

\author{
DOI: $10.46932 / \operatorname{sjd} d v 2 n 2-039$
}

Received in: january 1st, 2020

Accepted in: March 30th, 2020

\author{
Carlos Freddy Macías Cantos \\ $\mathrm{PhD}$ from the Universidad Del Zulia \\ E-mail: fredmacan@gmail.com
}

\begin{abstract}
The research focused on the use of the comprehensive model as a pedagogical instrument in the physical education class for university students. Theoretically, it was based on the contributions that originated in the proposals of Bunker and Thorpe (1982), at the University of Loughborough, who proposed the socalled comprehensive approach to the teaching of games or sports, Teaching Games for Understanding (TGfU) , Didactic Manual of the Socio-Sports Foundation Real Madrid (2015), Martin, Nicolaus, Ostrowski and Rost (2004), Benedek Endre (2006), among others. Content analysis was used for the development of the research. Among the methodological principles, the following stand out: -Integrative tasks for different contents, encourage maximum student participation (inclusion), development of perception, decision and execution mechanisms, problem solving (improvement of self-esteem, autonomy and creativity); Regarding pedagogical principles, it is based on the comprehensive model (appendix of constructivism), where the center of learning is the student and therefore the author of their own knowledge.
\end{abstract}

Keywords: Comprehensive model, sports learning, participation, reflection and critical analysis. Games.

\section{INTRODUCTION}

The university is the entity in charge of leading research processes and generating knowledge and the training of professionals for the integral progress of society. In this sense, the right to higher education should reside in praxis, in equal opportunities, based on the pertinent, relevant and excellence merits.

However, another great challenge for the university is to expand the quality of its academic, research, outreach and student welfare services: medical, social assistance, educational loans (scholarships), adequate infrastructure, libraries with a wide variety of books . If universities neglect these services, they stop providing conditions for the good academic development of their students, drastically reducing student satisfaction and their genuine interest in educating themselves (Motefakker, 2016). However, there is little interest in the development of the quality of life, incorporating Physical Culture in their curriculum for each professional career, to improve the physical and mental health of their students. 
Education has the social function of guiding and training new generations and contributing to their preparation for life, providing the necessary knowledge aimed at intellectual and moral development and skills, habits of conduct and modes of action. For this reason it is reiterated that sport and physical education constitute a complex higher activity of a scientific, comprehensive and globalized nature, becoming for many a lifestyle, beyond a discipline and a way of doing physical exercises. Hence, comprehensive and participatory teaching models present didactic contributions that will allow a more holistic, systemic and inclusive approach through physical education classes in higher education centers.

Therefore, the implementation of the comprehensive model in physical education classes in universities is considered very fundamental, as a transversal axis and inculcation of values that generate greater awareness and social orientation of all members of the university educational community, as a strategy to combat socio-axiological and health difficulties (physical and mental), raised among students, teachers and university authorities.

The comprehensive model is based on the development of tactics and strategy and the technique is logically integrated; fighting with the traditional method, the same as according to Bunker and Thorpe (1992, p. 186), there is little teaching of sports games, there is a poor decision-making capacity of the players; In other words, training consists of an excess of dependence on the teacher / coach (behavioral predominates).

For Cajigal, the game is the "free, spontaneous, disinterested and inconsequential action that takes place in a temporal and spatial limitation of habitual life, according to certain rules, established or improvised and whose informative element is tension" (Dinza, S 2011, p.3). This definition highlights that for motor activity to be effective, certain pedagogical and didactic requirements must be met: inclusion, participation, initiative, self-esteem, autonomy, etc., required and highlighted in this research.

\section{OBJECTIVES}

General objective

Promote physical education classes through the comprehensive model for the development of skills in higher education students.

Specific objectives

- Promote a Physical Education class that makes it possible to redeem the communication channels between students to favor the processes of their coexistence.

- Establish the level of theoretical-methodological and psycho pedagogical preparation of Physical Education teachers at ESPAM. 
- Prescribe the application of educational objectives and actions, considering the individual characteristics of their socio-community, cultural and family environment of university students.

-Stipulate the methodological principles that characterize the comprehensive model as a pedagogical tool in the teaching of physical education at ESPAM.

\section{METHOD / DESIGN}

The type of research that was carried out was documentary and hermeneutic, whose information aided in the investigation of information from writings such as texts, magazine articles, research papers and electronic materials that deal with issues related to the comprehensive model.

In the method used in this research is the comprehensive model, the physical education teacher cultivates the role of learning facilitator through the design of appropriate modified games and focuses on the individual and collective development of new knowledge through reflection. That is, the teacher decides on a tactical problem that has to be dealt with.

\section{RESULTS ACHIEVED}

The project: comprehensive physical education, results in physical education classes through the comprehensive model for the development of skills in university students, and then they can project their attitudes in the place where they are as professionals and citizens.

The results of this research are relevant for society, mainly for physical education teachers. And, to the students who will be benefited with a more adequate, dynamic pedagogical training; and to the educational community in general for the formative development of students who will have the opportunity to promote their creativity and problem solving through the comprehensive model where athletes are the protagonists.

Through the incorporation of the comprehensive model in the physical education classes of higher education students, it has been possible to improve motivation, camaraderie and a more participatory environment. But above all to combat sedentary lifestyle and enhance the physical and mental health of each individual. In this way, exclusion and mimicry or traditional models have been fought, reflected over time with monotonous, traditional, boring classes and few creative ones.

\section{CONCLUSIONS}

-The comprehensive model helps to enhance physical education classes, promoting better development of skills and sociability in higher education students. 
- The level of theoretical-methodological and psycho pedagogical preparation of physical education teachers is not yet in tune with the application of this model.

- The fulfillment of the educational objectives and actions does not respond to its sociocommunity, cultural and family environment due to the little participation of its actors.

-The development of the blocks or contents contemplated in the physical education curriculum in university students continues to be direct.

-The application of the principles of the comprehensive model in the teaching of physical education in ESPAM is deficient.

\section{RECOMMENDATIONS.}

-The University Student Welfare Departments must analyze their functions related to the members of the university community, in order to guarantee the physical, emotional and social health of the students.

-Measures should be taken to encourage the interest of the university community for the participation and development of Physical Education programs.

-The University must provide sources of information to the university community about the services and benefits provided by the Student Welfare Department so that its students know their benefits. Among them the physical education, sports and training programs.

-The University must include among its services, curriculum and / or transversal axes; Physical Education classes that favor the psychological, social, cultural and physical development of students. And therefore the improvement of the quality of life of its university community. 


\section{BIBLIOGRAPHIC REFERENCES}

- $\quad$ Benedek Endre (2006), Children's football. Editorial Paidotribo. P. 13-14-23-33. Spain.

- $\quad$-Bunker, D., and Thorpe, R. (1982). A model for the teaching of games in secondary schools. Bulletin of Physical Education, 18 (1), 5-8.

- -Dinza, S. Citing Piaget, J. (2011), Game Theory, retrieved from http://www.imetyd.org.mx/.

- $\quad$-Teaching manual, Real Madrid Socio-Sports Foundation (22015). Coaching soccer, teaching values. P. 18. 25-29.

- $\quad$ - Martin D.- Nicolaus J.- Ostrowski Ch. And Rost K (2004). General methodology of child and youth training. Editorial Paidotribo. Page 12. Spain.

- $\quad$-Motefakker, N. (2016). The Study of the Level of Satisfaction of the Students of the Faculty of Social Sciences with Welfare Services of Imam Khomeini International University of Qazvin. Procedia Economics and Finance, 36, 399-407. http://doi.org/10.1016/S2212-5671(16)30052-1

- $\quad$ - Thorpe, R. (1997). Understanding in children's play: an alternative approach to teaching sports games. In J. Devís and C. Peiró (Coords.), New curricular perspectives in Physical Education: health and modified games. Barcelona: Inde. 